\title{
IMPLEMENTATION ANALYTICAL HIERARCHY PROCESS AND WEIGHTED PRODUCT METHOD FOR LOVEBIRD SELECTION IDENTIFICATION APPLICATIONS
}

\author{
Yolanda Nur Oktavia ${ }^{1}$, Nurhayati ${ }^{2}$, Iskandar Fitri ${ }^{3 *}$ ) \\ Sistem Informasi, Fakultas Teknologi Komunikasi dan Informatika, Universitas Nasional \\ yolandanuroktavia2018@student.unas.ac.id12,nurhayati@civitas.unas.ac.id², \\ iskandar.fitri@civitas.unas.ac.id ${ }^{\left.3^{*}\right)}$
}

(*)Corresponding Author

\begin{abstract}
Abstrak
Diantara banyaknya jenis burung di Indonesia burung lovebird adalah hewan peliharaan yang paling banyak menarik perhatian dan menjadi favorit di kalangan masyarakat. Hal ini dibuktikan dengan sekian banyaknya komunitas pencinta lovebird di seluruh penjuru Indonesia. Permasalahan yang ada bagi orang awam yang kurang paham tentang dunia hewan dan memiliki pengetahuan yang sedikit mengenai bagaimana kualitas burung lovebird tersebut, tidak jarang kendalanya ialah dalam berbisnis bagi penjual sulit untuk memilih keputusan dalam mengatasi masalah pemilihan burung terbaik. Atas permasalahan tersebut penulis melakukan perbandingan kombinasi metode analytical hierarchy process dan weighted product dengan analytical hierarchy process dan TOPSIS dari perbandingan tersebut diperoleh nilai tertinggi sebesar 392.63 pada analytical hierarchy process dan weighted product untuk aplikasi perancangan aplikasi rekomendasi seleksi lovebird berkualitas terbaik berbasis website. Dari hasil pengujian aplikasi maupun perhitungan manual dengan 64 data sampel disimpulkan 4 pengguna atau sekitar 6\% masuk pada kategori ketepatan rendah dalam hasil perekomendasian lovebird terbaik, 12 pengguna atau sebesar 19\% dari seluruh total pengujian dinyatakan pada dengan tingkat kategori ketepatan sedang dalam hasil perekomendasian lovebird terbaik dan 48 pengguna atau sebesar $75 \%$ dari seluruh total pengujian dinyatakan pada dengan tingkat kategori ketepatan tinggi dalam hasil perekomendasian lovebird terbaik dengan nilai ketepatan tertinggi sebesar $80.2 \%$ pada jenis lovebird Albino.
\end{abstract}

Kata kunci: Sistem Pendukung Keputusan, Lovebird,, Berkualitas, Kombinasi, AHP, WP

\begin{abstract}
Among the many types of birds in Indonesia, lovebirds are pets that attract the most attention and become a favorite among the public. This is evidenced by the many communities of lovebird lovers throughout Indonesia. The problem that exists for ordinary people who do not understand the animal world and have little knowledge about the quality of the lovebirds, it is not uncommon for the problem to be in doing business for sellers it is difficult to make decisions in overcoming the problem of selecting the best birds. Based on this problem, the author compares the combination of the analytical hierarchy process and weighted product methods with the analytical hierarchy process and TOPSIS from this comparison, the highest score is 392.63 on the analytical hierarchy process and weighted product for the best quality webbased lovebird selection recommendation application design application. From the results of application testing and manual calculations with 64 sample data, it was concluded that 4 users or about $6 \%$ were included in the low accuracy category in the best lovebird recommendation results, 12 users or $19 \%$ of the total tests were stated at a moderate level of accuracy in the lovebird recommendation results. The best and 48 users or $75 \%$ of the total tests were stated at the high accuracy category level in the best lovebird recommendation results with the highest accuracy value of $80.2 \%$ on the Albino lovebird type.
\end{abstract}

Keywords: Decision Support System, Lovebird, Quality,Combination, AHP, WP

\section{INTRODUCTION}

Lovebirds are currently kept by many people because they have a melodious chirping sound and beautiful color gradations in the appearance of their feathers. The various types of lovebird names and their criteria are very unique and varied, so that they affect the price on the market every year depending on the season and the physical quality of the lovebird. Cases of problems in the system to be built are interrelated. 
The type of poultry that is in demand on the market in the livestock category at this time is the lovebird. So that the interest from buyers who are looking for and buying the bird is very high. This of course requires the shop owner to understand the quality of good birds to sell to buyers. The problem is from the side of the seller who is still new to the business in the pet sector. The offer of a bird provider from a supplier is often rejected by the seller because it avoids the risk of loss due to not understanding the quality of a good lovebird for sale. The loss that occurred was that they had experienced fraud against the condition of the bird which was in fact unhealthy and imperfect, and in the end it affected income so that turnover decreased. As a result, the seller decided to stop selling lovebirds, to help the seller's decision problem in making it easier to choose a quality lovebird, a decision support system was made that can be used so as to increase buyer satisfaction.

The research which in this case discusses the selection of pigeons that has been carried out previously in 2021 by A.Ramadhan et al., namely the application produced is very user friendly and the admin or user does not find it difficult to determine the best quality of pigeons with the conclusion of determining the highest ranking alternative of 0.327 in system(Ramadhan, Suprianto, Surmarno, \& Dijaya, 2021).

Other research is still on the same topic, namely the recommendation for selecting different types of chirping birds in 2019 by R.Rudiantoro et al by testing several different bird species to find out which sings best and the final result shows the highest preference value of 6.34 for the lovebird species.(Rudiantoro, Cholissodin, \& Dewi, 2019).

In a further study regarding similar research objects in 2019 conducted by S. Bahtiar et al, namely lovebirds, which aims to assist the judges in objectively assessing the best bird competition contest. The output generated by computerization and manual calculation is the same with the highest value reaching 1.85(Bahtiar, Gunawan, Safii, \& Parlina, 2019).

The next similar research conducted by E.L Amalia et al in 2019 was about determining in choosing the most superior lovebird in the competition. Application with a combination of AHP and TOPSIS methods (Amalia, RDA, \& Pratama, 2019). The system is made to determine the best quality in determining the assessment in decision making in the competition so that it can help the judges with an accuracy rate of $98 \%$ system with manual calculations.

Then further research is still using the same method but with a different title for the discussion in 2021 conducted by S. Defit et al., discussing a system that identifies the quality of a wallet bird's nest with the application of the weighted product method. The results of this system show the ranking data well with an accuracy level reaching 100\% according to manual calculations and applications(Defit, Nurcahyo, Studi, \& Ilmu, 2021).

However, research related to the selection of lovebirds and using a combination of analytical hierarchy process and weighted product on the same issue has not been found before. For this reason, the author proposes a combination of analytical hierarchy process and weighted product methods in this study regarding a recommendation system for selecting quality lovebirds that can be used by ordinary people, especially bird sellers to determine good quality for sale to buyers. The selection of the AHP and WP methods was based on the results of the comparison test of the combination of these methods with other methods, namely the analytical hierarchy process and the technique for others reference by similarity to ideal solution (TOPSIS)(Amalia et al., 2019) using the Mean Squared Error (MSE) forecasting model to find out which method is the best (Sugianto, Roslina, \& Situmorang, 2021). The final result shows the highest value in the AHP-WP combination, which is 392.63 , it can be concluded that the AHP-WP method is the best and most accurate method of research in determining the selection of quality lovebirds. It is hoped that with this decision support system in the application of recommendations for determining quality lovebirds, it can overcome decisions in choosing which types meet the good quality of lovebirds precisely and accurately.

\section{RESEARCH METHODS}

The stages of research are carried out so that the plan can be neatly arranged and get maximum results.

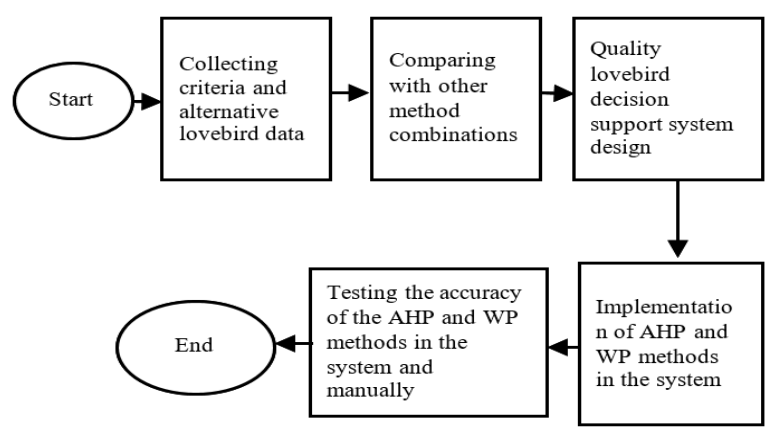

Figure 1. Research Framework

Figure 1 describes the framework of the stages in the preparation of this research, starting with collecting data on criteria and alternative lovebirds, then comparing the combination of 
methods used with other combination methods, then making a system design after applying the AHP and WP methods into the system and finally doing testing. to determine the level of system accuracy.

\section{Collecting data}

This study relies on reference weighting criteria data derived from journals, interviewing interviewees of resource persons observation data from bird breeding places, in addition to strengthening other official sources as well as from the Indonesian lovebird breeding website.(DLHK Provinsi Banten, 2019) then processed manually as needed to design a decision support system(Defit et al., 2021). The data criteria are variables used in calculating the best lovebird quality recommendations

Table.1 List of Criteria and Sub Criteria

\begin{tabular}{|c|c|c|c|}
\hline Code & Criterions & Sub Criteria & $\begin{array}{c}\text { Preference } \\
\text { Value }\end{array}$ \\
\hline \multirow{4}{*}{ KC1 } & \multirow{4}{*}{$\begin{array}{c}\text { Beak } \\
\text { Shape }\end{array}$} & Dry Short & 1 \\
\hline & & Thin Pointy & 3 \\
\hline & & Thick & \\
\hline & & Curved & 5 \\
\hline \multirow{3}{*}{ KC2 } & \multirow{4}{*}{ Foot } & Paralyzed & 1 \\
\hline & & Limp & 3 \\
\hline & & Gripping & 5 \\
\hline \multirow{4}{*}{ KC3 } & & Oval Shape & 1 \\
\hline & \multirow{3}{*}{$\begin{array}{l}\text { Head } \\
\text { Shape }\end{array}$} & $\begin{array}{l}\text { Round } \\
\text { Shape }\end{array}$ & 3 \\
\hline & & Protruding & 5 \\
\hline & & Forehead & 5 \\
\hline \multirow{3}{*}{ KC4 } & \multirow{3}{*}{ Posture } & Disability & 1 \\
\hline & & $\begin{array}{l}\text { No Defects } \\
\text { (Standard) }\end{array}$ & 3 \\
\hline & & Proportional & 5 \\
\hline \multirow{4}{*}{ KC5 } & \multirow{4}{*}{$\begin{array}{c}\text { Fur } \\
\text { Condition }\end{array}$} & Loss & 1 \\
\hline & & Tidy & 3 \\
\hline & & Soft & 5 \\
\hline & & Shiny & 7 \\
\hline \multirow{3}{*}{ KC6 } & \multirow{3}{*}{ Behaviour } & $\begin{array}{l}\text { Silent } \\
\text { Snuggle }\end{array}$ & 1 \\
\hline & & Very Agile & 3 \\
\hline & & $\begin{array}{l}\text { Sounding } \\
\text { Voice }\end{array}$ & 5 \\
\hline
\end{tabular}

Table 1 shows a list of types of criteria or physical characteristics of lovebirds as many as 6 criteria names and has each sub-criterion consisting of codes $\mathrm{C} 1$ to $\mathrm{C} 6$ that have been determined and processed preference values by related sources. Furthermore, alternative data are the names of lovebird species that belong to 9 species of the genus Agapornis(Charli, Syaputra, Akbar, Sauda, \& Panjaitan, 2020). And the assessment will be done is one of these types is the type of Agapornis roseicollis.
Table.2 List of Alternatives to Lovebird Options

\begin{tabular}{cc}
\hline $\begin{array}{c}\text { Alternative } \\
\text { Code }\end{array}$ & Alternative Name \\
\hline L1 & Lovebird Albino \\
L2 & Lovebird Lutino \\
L3 & Lovebird Golden Cherry \\
L4 & Lovebird Pied \\
L5 & Lovebird Cinnamon \\
L6 & Lovebird Biru \\
\hline
\end{tabular}

Table 2 contains data on lovebird names displayed as many as 6 tails of the same species, data obtained from the indonesian lovebird farming website (DLHK Provinsi Banten, 2019) It consists of each of the alternative codes from L1 to L6 applied to the study.

\section{Comparison of Method Combinations}

After collecting the data needed to find out the consistency of precision and accuracy of which combination of methods will be applied to this study, a comparison test is conducted. By comparing 2 other method combinations namely analitycal hierarchy process and weighted product with analitycal hierarchy process and technique for others reference by similarity to ideal solution. With the formula of the combination method ahp and WP (Krismadewi, 2021)

$$
\begin{aligned}
& \Lambda \text { maks }=\frac{\text { Jumlah }}{\mathrm{n}} \\
& \text { CI }=\frac{\wedge m a k s-n}{n} \\
& \mathrm{CR}=\frac{C I}{I R} \\
& \mathrm{CR}=\text { ratio consistency } \\
& \text { CI = index consistency } \\
& \mathrm{n}=\text { the number of elements } \\
& \text { IR = random index }
\end{aligned}
$$

The preference for $\mathrm{Ai}$ alternatives starts from looking for vector values $\mathrm{S}$ and vector $\mathrm{V}$

$$
\begin{aligned}
& S_{i}=\prod_{j}^{n}=1^{X_{i j}{ }^{W j}} . \\
& V_{i}=\frac{\prod_{j}^{n}=1^{X_{i j}{ }^{W j}}}{\prod_{j}^{n}=1^{X_{i j}{ }^{W j}}{ }^{W W j}} .
\end{aligned}
$$

Stated, $i$ is the result of alternative preferences to $-i$ and $\Pi$ is the sum of the results of the multiplication of alternative rankings of each attribute. And the results showed the highest and lowest values(Perdana, Defit, \& Sumijan, 2020).

Furthermore, the formula combination of AHP and Topsis methods is used to determine the final data results (Amalia et al., 2019). For the 
formula AHP is the same as the equation(1) and continued with the formula Topsis.

The method comparison process in this study uses the Mean Squared Error (MSE)forecasting model to find out which method is best(Sugianto et al., 2021). The formula for calculating MSE is:

MSE $=\frac{\sum e_{i}{ }^{2}}{n}=\frac{\sum\left(X_{i}-F_{i}\right)^{2}}{n}$

$$
\begin{array}{ll}
\mathrm{Xi} & : \text { Preliminary Data } \\
\mathrm{Fi} & : \text { Final Data } \\
\mathrm{n} & \text { : Number of criteria }
\end{array}
$$

The first step is done by determining the initial amount of data from each criterion and alternative. Then calculate the deviation value of

\begin{tabular}{|c|c|c|}
\hline $\begin{array}{c}\text { Preliminary } \\
\text { Data }\end{array}$ & Final Data & (Deviation) $^{2}$ \\
\hline 20 & 0.185 & 392.63 \\
\hline 20 & 0.146 & 394.18 \\
\hline 18 & 0.249 & 315.09 \\
\hline 20 & 0.152 & 393.94 \\
\hline 16 & 0.137 & 251.63 \\
\hline 20 & 0.131 & 394.77 \\
\hline \multicolumn{2}{|c|}{ Sum } & 2355.78 \\
\hline
\end{tabular}
each method.

Table 3 Determination of Deviation of AHP-WP

Table 3 contains the initial data obtained from the sum of the comparison of criteria of the AHP method and the final data is obtained from the total calculation of the AHP and WP methods. Then count using the equation (4).

MSE $=2355.78 / 6=392.63$

\begin{tabular}{|c|c|c|}
\hline $\begin{array}{c}\text { Preliminary } \\
\text { Data }\end{array}$ & Final Data & (Deviation) $^{2}$ \\
\hline 20 & 0.494 & 380.48 \\
\hline 20 & 0.429 & 383.02 \\
\hline 18 & 0.678 & 300.05 \\
\hline 20 & 0.442 & 382.51 \\
\hline 16 & 0.437 & 242.20 \\
\hline 20 & 0.372 & 385.25 \\
\hline \multicolumn{2}{|c|}{ Sum } & 2073.51 \\
\hline
\end{tabular}

Table.4 Determination of Deviation of AHPTOPSIS

Table 4 contains the initial data obtained from the sum of the comparison of criteria of the AHP method and the final data is obtained from the total calculation of the AHP and Topsis methods. Then calculate using the equation (1).

\begin{tabular}{|c|c|c|}
\hline No & Combination of Methods & MSE \\
\hline 1 & $\begin{array}{l}\text { analytical hierarchy process } \\
\text { dan weighted product }\end{array}$ & 392.63 \\
\hline 2 & $\begin{array}{l}\text { analytical hierarchy rocess dan } \\
\text { TOPSIS }\end{array}$ & 345.58 \\
\hline & Max Deviasi & 392.63 \\
\hline
\end{tabular}

MSE $=2073.51 / 6=345.58$

Table.5 Final Results of Method Comparison

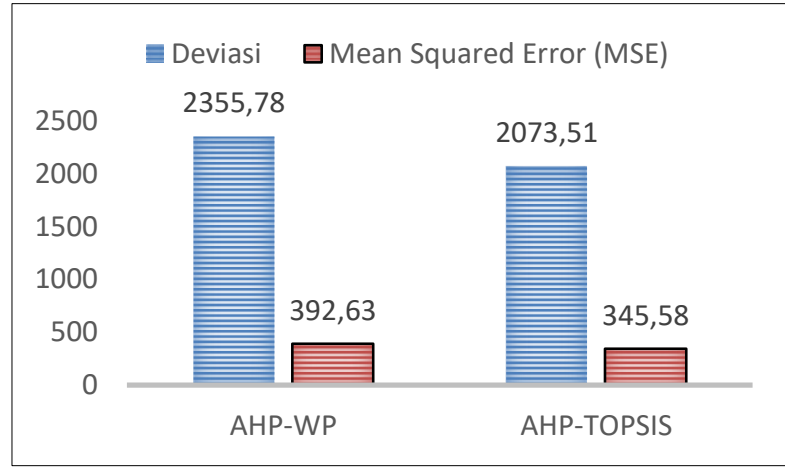

Figure2. End Results of Method Comparison

Based on Table 5 it can be determined that the visualization of the graph calculation of the bar diagram shows the AHP-WP method gets a deviation value of 2355.78 and a total of MSE 392.63 and the AHP-TOPSIS method gets a deviation value of 2073.51 and a total of MSE 345.58 , so the researcher decided to use the combination of AHP-WP methods as the basic reason for producing the highest value in determining the selection of quality lovebirds (Imam, 2020).

\section{System Creation}

Creation starts from research on criteria data and criterion values. The creation of a flow overview of the implementation of the analitycal hierarchy process and weighted product method can be seen in the flowchart image(Novira, Mubarok, \& Shofa, 2020):

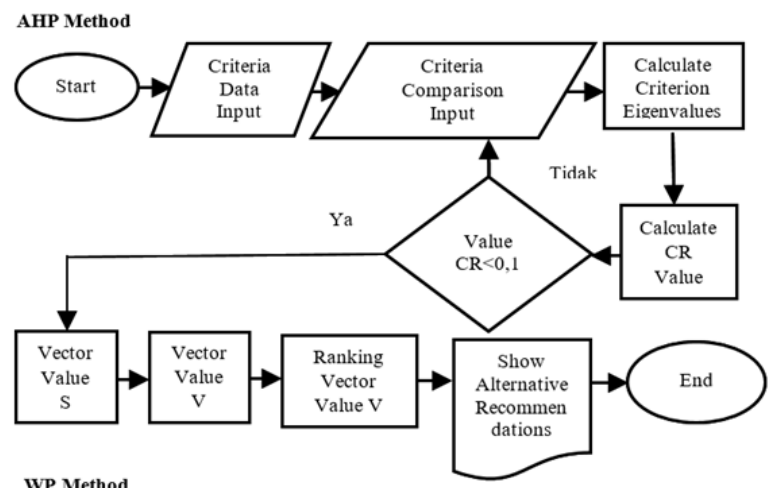

Figure 3. Flowchart System

Figure 3 can be explained that the flow of the system design begins by using the analytical hierarchy process method. The first process is to input the criteria data, then continue by inputting 
JURNAL RISET INFORMATIKA

Vol. 4, No. 1 December 2021

the weights for each criterion, then the system will calculate the eigenvalues and CR values to find out the logical consistency of the criteria. calculate the value of vector $S$ then vector $\mathrm{V}$ and arrive at the ranking of vector values so that it can display alternative recommendations based on the highest rank.

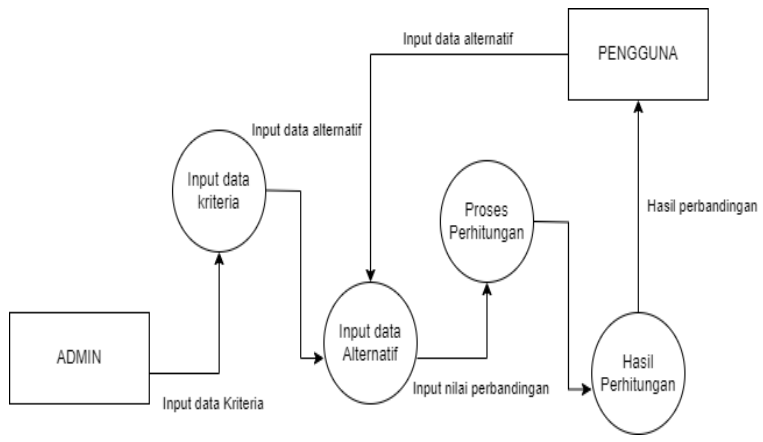

Figure 4. Data Flow Diagram

In Figure 4 of the system's data flow diagram for admins and users. The administrator's role is to manage system work starting from login and then inputting each criterion and preference weight value on alternative data and criteria. Then the role of the user is to input some alternative data that will later be processed by the system and produce a calculation output in the form of a list of the best quality lovebirds (Ramadhan et al., 2021).

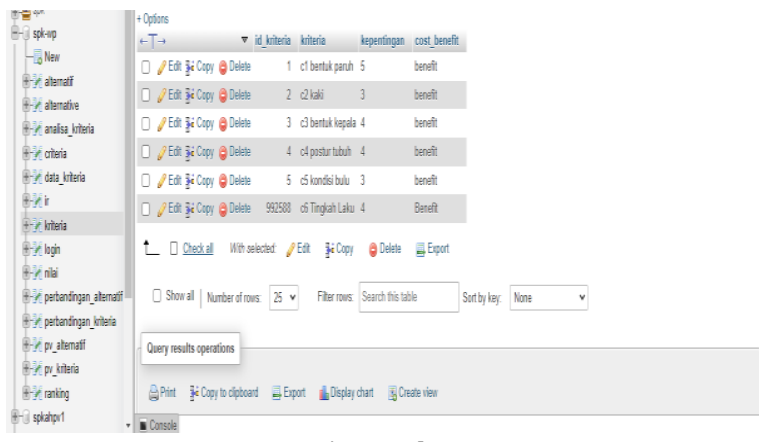

Figure 5. Database View

The next stage is to create a database containing 12 tables with results in the database view in Figure 5 which is used to accommodate table data both input and output in the application of quality lovebird selection decision support system.
P-ISSN: 2656-1743 |E-ISSN: 2656-1735

DOI: https://doi.org/10.34288/jri.v4i1.305

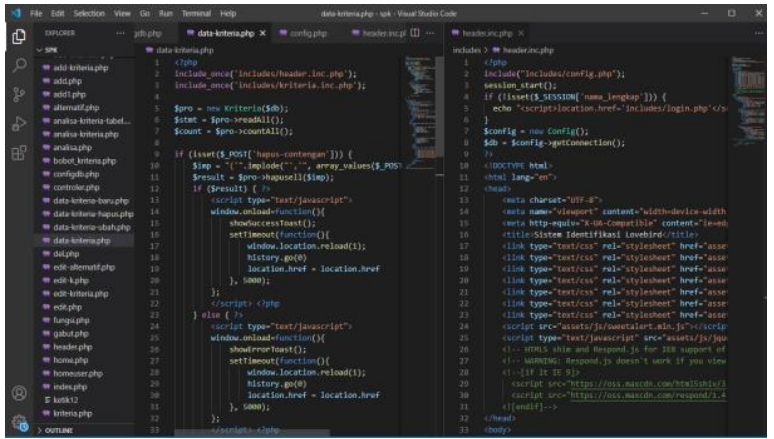

Figure 6. Program Code View

After creating the database, in Figure 6 is designed in the form of a coding structure using the PHP Native programming language with visual studio code editor software, which begins to create a framework with Bootstrap, to produce a website application support system for choosing the best lovebird decision from the input process to output that can be run.

\section{System Implementation}

The application of this system is websitebased using php native, HTML, and mySQL languages as databases used. The interface results of this SPK system consist of login pages, home, criteria data, alternative data, analysis, and calculations.

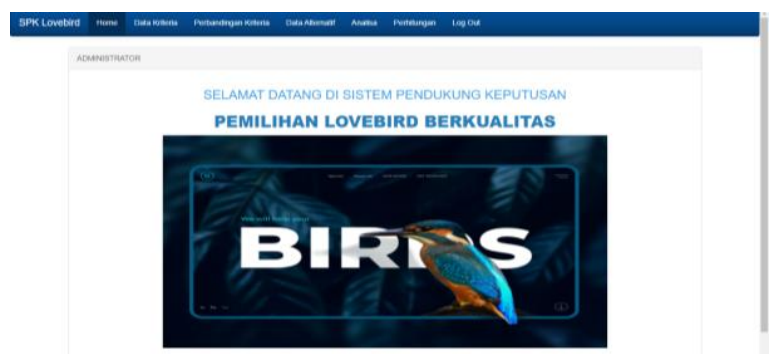

Figure 7. Home View

In figure 7 is the main page and there are several menus, namely criteria data, alternative data, analysis, and calculations.

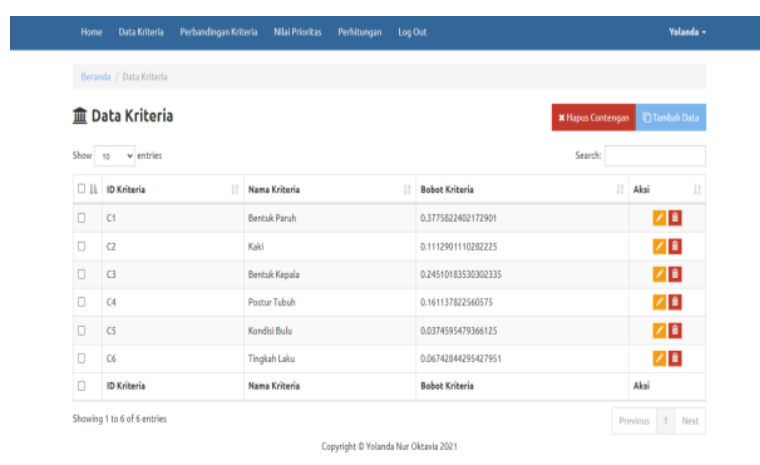

Figure 8. Criteria Data View 
In figure 8 is a menu that contains criteria information consisting of the criteria id, the name of the criteria, the weight of the criteria, and then the option to edit.

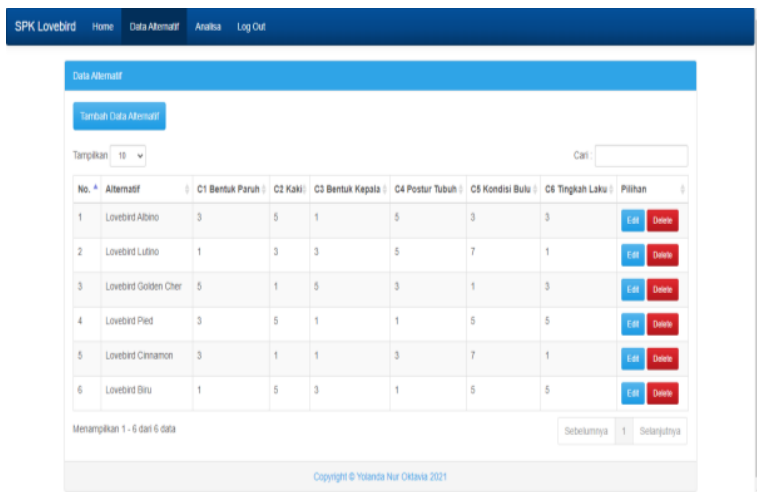

Figure 9. Alternative Data View

Figure 9 is an alternative data menu that features add alternative data and options for editing and deleting. In addition, there is a search feature to search for the required data using keywords quickly.

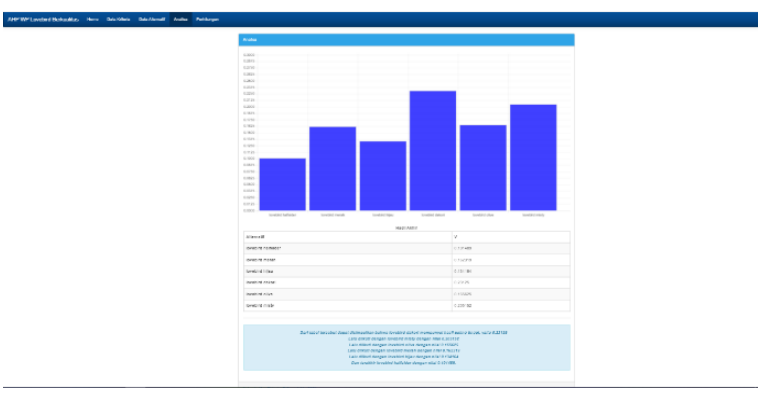

Figure 10. Analysis View

In figure 10 is an analysis menu whose function provides a graph of the results of calculations done to choose a quality lovebird

\section{RESULTS AND DISCUSSION}

\section{Determining Criteria and Weighting}

Based on the information that has been collected by direct observation in the field, some quality lovebird criteria that have the following characteristics that will be applied to the AHP method are:

Table 6. Physical Characteristics

\begin{tabular}{ccc}
\hline Kode & Kriteria & Jenis \\
\hline KC1 & Beak shape & Benefits \\
KC2 & Foot & Benefits \\
KC3 & Head Shape & Benefits \\
KC4 & Posture & Benefits \\
KC5 & Fur Condition & Benefits \\
KC6 & Behavior & Benefits \\
\hline
\end{tabular}

Table 6 classifies criteria based on the physical characteristics of a lovebird. Where because all criteria have a value weight that the higher the value means the better, then it belongs to the category of benefits.

Table 7. Criteria Comparison Matrix

\begin{tabular}{lllllll}
\hline & KC1 & KC2 & KC3 & KC4 & KC5 & KC6 \\
\hline KC1 & 1.00 & 4.00 & 2.00 & 3.00 & 7.00 & 5.00 \\
KC2 & 0.25 & 1.00 & 0.33 & 0.50 & 5.00 & 2.00 \\
KC3 & 0.50 & 3.00 & 1.00 & 2.00 & 4.00 & 5.00 \\
KC4 & 0.33 & 2.00 & 0.50 & 1.00 & 5.00 & 3.00 \\
KC5 & 0.14 & 0.20 & 0.25 & 0.20 & 1.00 & 0.33 \\
KC6 & 0.20 & 0.50 & 0.20 & 0.33 & 3.00 & 1.00 \\
Sum & 2.43 & 10.7 & 4.28 & 7.03 & 25.00 & 16.33 \\
\hline
\end{tabular}

In Table 7 to determine the assessment, a comparison of the criteria comparison matrix (Andriyani \& Yuma, 2020). The description is based on the level of importance of the criteria compared to other criteria. The weighting of each criterion is based on determining the ahp formula that has been determined according to the priority interests obtained from the table(Andriyani \& Yuma, 2020)

Table 8. Saaty Table

\begin{tabular}{|c|c|c|}
\hline Value & Definition & Information \\
\hline 1 & $\begin{array}{l}\text { Equally - equally } \\
\text { important }\end{array}$ & $\begin{array}{l}\text { Both have the same } \\
\text { influence. }\end{array}$ \\
\hline 3 & $\begin{array}{l}\text { A Little } \\
\text { Important }\end{array}$ & $\begin{array}{l}\text { The ratio of one is } \\
\text { slightly higher than } \\
\text { the second. } \\
\text { The ratio of one is }\end{array}$ \\
\hline 5 & More Important & $\begin{array}{l}\text { higher than the } \\
\text { second. }\end{array}$ \\
\hline 7 & Very Important & $\begin{array}{l}\text { The ratio of one is } \\
\text { very higher than the } \\
\text { second. }\end{array}$ \\
\hline 9 & $\begin{array}{l}\text { Absolutely } \\
\text { Essential }\end{array}$ & $\begin{array}{l}\text { The ratio of one is } \\
\text { absolutely very } \\
\text { strong from the } \\
\text { second. }\end{array}$ \\
\hline $2,4,6,8$ & $\begin{array}{l}\text { Value } \\
\text { them }\end{array}$ & $\begin{array}{l}\text { Both have an } \\
\text { adjacent } \\
\text { assessment. }\end{array}$ \\
\hline
\end{tabular}

Table 8 is a saaty table that has a relative importance level value between two criteria based on the decision maker's assessment and will form a paired comparison matrix(Nurajizah, Ambarwati, \& Muryani, 2020).

Table 9. Synthesis of Criteria Comparison

\begin{tabular}{|c|c|c|c|c|c|c|c|}
\hline \multicolumn{6}{|c|}{ Number of Each Element } & \multirow{2}{*}{\begin{tabular}{|l|}
$\mathrm{Su}$ \\
$\mathrm{m}$
\end{tabular}} & \multirow{2}{*}{$\begin{array}{l}\text { Averag } \\
\text { e } \\
0.38\end{array}$} \\
\hline 0.4 & 0.3 & 0.4 & 0.4 & 0.2 & 0.3 & & \\
\hline 1 & 7 & 7 & 3 & 8 & 1 & 7 & \\
\hline 0.1 & 0.0 & 0.0 & 0.0 & 0.2 & 0.1 & 0.6 & 0.11 \\
\hline $\mathbf{0}$ & 9 & 8 & 7 & 0 & 2 & 7 & \\
\hline 0.2 & 0.2 & 0.2 & 0.2 & 0.1 & 0.3 & 1.4 & 0.25 \\
\hline 1 & 8 & 3 & 8 & 6 & 1 & 7 & \\
\hline
\end{tabular}


JURNAL RISET INFORMATIKA

Vol. 4, No. 1 December 2021

\begin{tabular}{llllllll}
$\mathbf{0 . 1}$ & 0.1 & 0.1 & 0.1 & 0.2 & 0.1 & $\mathbf{0 . 9}$ & $\mathbf{0 . 1 6}$ \\
$\mathbf{4}$ & 9 & 2 & 4 & 0 & 8 & $\mathbf{7}$ & \\
$\mathbf{0 . 0}$ & 0.0 & 0.0 & 0.0 & 0.0 & 0.0 & $\mathbf{0 . 2}$ & $\mathbf{0 . 0 4}$ \\
$\mathbf{6}$ & 2 & 6 & 3 & 4 & 2 & $\mathbf{2}$ & \\
$\mathbf{0 . 0}$ & 0.0 & 0.0 & 0.0 & 0.1 & 0.0 & $\mathbf{0 . 4}$ & $\mathbf{0 . 0 7}$ \\
$\mathbf{8}$ & 5 & 5 & 5 & 2 & 6 & $\mathbf{0}$ & \\
\hline
\end{tabular}

Table 9 is the result of the calculation of each element and the number and average of the elements form a comprehensive comparison table of standards that will be used as the basis for ranking criteria. The next step is to calculate the consistency ratio (CR). By calculating the first contingency index (CI) using the equation (1).

$$
\begin{aligned}
\mathrm{CI}= & \frac{\wedge m a k s-n}{n} \\
\Lambda \text { maks }= & \\
& \left(2.43^{*} 0.38\right)+\left(10.7^{*} 0.12\right)+\left(4.28^{*} 0.25\right)+( \\
& \left.7.03^{*} 0.16\right)+\left(25^{*} 0.04\right)+\left(16.33^{*} 0.07\right)= \\
& 6,533 \\
= & 6 \\
\mathrm{n} \quad= & (6,533-6) /(6-1)=0,106 \\
\mathrm{CI} \quad \mathrm{CR} \quad & \mathrm{CI} / \mathrm{IR}=0,106 / 1,24=0,085
\end{aligned}
$$

Referring to the above point of 0.085 it can meet the provisions of $\mathrm{CR}<0.1$ so that the process of analyzing quality lovebird selection criteria is said to be consistent.

The result of calculating the above average value is the main weight or component of each criterion, and certainly becomes the preferred weight of the WP method. Then continued with the calculation of the WP method that determines some alternatives to lovebird and previous criteria to get a quality type ofovebird $\mathrm{l}$.

Table 10. Alternative Value Criteria

\begin{tabular}{ccccccc}
\hline \multirow{2}{*}{ Alternatif } & \multicolumn{7}{c}{ Criterions } \\
\cline { 2 - 7 } & KC1 & KC2 & KC3 & KC4 & KC5 & KC6 \\
\hline L1 & 3 & 5 & 1 & 5 & 3 & 3 \\
L2 & 1 & 3 & 3 & 5 & 7 & 1 \\
L3 & 5 & 1 & 5 & 3 & 1 & 3 \\
L4 & 3 & 5 & 1 & 1 & 5 & 5 \\
L5 & 3 & 1 & 1 & 3 & 7 & 1 \\
L6 & 1 & 5 & 3 & 1 & 5 & 5 \\
\hline
\end{tabular}

Table 10 is a data input by the user that displays the preference value based on the type of lovebird with its sub criteria referring to Table 1 and then is the initial data in the determination of the deviation of AHP-WP in Table 3.

Table11. Preference Weights

\begin{tabular}{llllll}
\hline KC1 & KC2 & KC3 & KC4 & KC5 & KC6 \\
\hline 0.38 & 0.11 & 0.25 & 0.16 & 0.04 & 0.07 \\
\hline
\end{tabular}

P-ISSN: 2656-1743 |E-ISSN: 2656-1735

DOI: https://doi.org/10.34288/jri.v4i1.305

Table 11 is the result of calculating the average value of each criterion in table 12 and will be the power value in the next calculation step.

\section{Determining Vector Value $S$}

The next step is to determine the vector $\mathrm{S}$, i.e. by adjusting the weight of the criteria and multiplying by the weight of each preference using the equation (2).

Tabel 12. Vector Class $S$

\begin{tabular}{cc}
\hline Vector Value S & Result \\
\hline VS1 & 2,645 \\
VS2 & 2,076 \\
VS3 & 3,548 \\
VS4 & 2,163 \\
VS5 & 1,956 \\
VS6 & 1,875 \\
\hline Sum & 14,265 \\
\hline
\end{tabular}

Table 12 is the result of the weight of the data from each calculation of the value of the vector $S$ of each alternative.

\section{Determining value $\mathbf{V}$}

The next determination is the process of playing by calculating vector classes. That is, the result of dividing the value of weight $S$ with the number of alternative rating multiplication results per attribute using the equation (3).

Table 13. Ranking Results

\begin{tabular}{ccc}
\hline VECTOR & RESULT & RANKING \\
\hline V1 & 0.185 & 2 \\
V2 & 0.146 & 4 \\
V3 & 0.249 & 1 \\
V4 & 0.152 & 3 \\
V5 & 0.137 & 5 \\
V6 & 0.131 & 6 \\
\hline
\end{tabular}

In Table 13 is a settlement in the assessment process in the form of a role. Based on the results of preference calculations in table 13. So in order of the best quality lovebird is the first rank of golden cherry lovebird with code L3, second rank albino lovebird with code L1, third rank lovebird pied with code L4, fourth rank lovebird lutino with code L2, fifth rank lovebird cinnamon with code L5, and last rank blue lovebird with code L6.

\section{Testing Results}

From the results of manual calculations that have been done by entering 6 different criteria obtained the final results of the assessment that has been included in reference to Table 13 has recommended the best quality lovebird that 
ranked first, namely the golden cherry lovebird with a value of 0.249 .

Table 14. Alternative Sample Data Input Scenario Testing Results

\begin{tabular}{|c|c|c|c|c|c|}
\hline No & Alternative Code \& Preference Value & $\begin{array}{l}\text { System } \\
\text { Values }\end{array}$ & $\begin{array}{l}\text { Manual } \\
\text { Value }\end{array}$ & $\begin{array}{l}\text { Highest } \\
\text { Rank }\end{array}$ & Desc \\
\hline 1 & $\begin{array}{l}\text { L1: [KC1.5], [KC2.5], [KC3.5], [KC4.5], [KC5.7], [KC6.5] ; L2: } \\
\text { [KC1.3], [KC2.1],[KC3.3], [KC4.1], [KC5.1], [KC6.3] }\end{array}$ & 0.704 & 0.704 & $\begin{array}{l}\text { Lovebird } \\
\text { Albino }\end{array}$ & 28 \\
\hline 2 & $\begin{array}{l}\text { L1: [KC1.3], [KC2 [5], [KC3.1], [KC4.5], KC5.3], [KC6.3]; L2: } \\
\text { [KC1.1], [KC2.3], [KC3.3], [KC4.5], [KC5.7], [KC6.1]; L3: [KC1.5], } \\
\text { [KC2.1], [KC3.5], [KC4.3], [KC5.1], [KC6.3]; ;4: [KC1.3], [KC2.5], } \\
\text { [KC3.1], [KC4.1], [KC5.5], [KC6.5]; L5: [KC1.3], [KC2.1], [KC3.1], } \\
\text { [KC4.53, [KC5.7], [KC6.1]; ;6 : [KC1.1], [KC2.5], [KC3.3], } \\
\text { [KC4.1], [KC5.5], [KC6.5] }\end{array}$ & 0.2487 & 0.249 & $\begin{array}{l}\text { Lovebird } \\
\text { Golden } \\
\text { Cherry }\end{array}$ & 63 \\
\hline 3 & $\begin{array}{l}\text { L4: [KC1.1], [KC2.5], [KC3.1], [KC4.1], [KC5.3], [KC6.5] ; L5: } \\
\text { [KC1.5], [KC2.5], [KC3.5], [KC4.5], [KC5.7], [KC6.5] }\end{array}$ & 0.786 & 0.786 & $\begin{array}{l}\text { Lovebird } \\
\text { Cinnamon }\end{array}$ & 12 \\
\hline 4 & $\begin{array}{l}\text { L4: [KC1.3], [KC2.5], [KC3.1], [KC4.1], [KC5.5], [KC6.5] ; L2: } \\
{[\text { KC1.3], [KC2.5], [KC3.3], [KC4.3], [KC5.3], [KC6.3] }}\end{array}$ & 0.5973 & 0.597 & $\begin{array}{l}\text { Lovebird } \\
\text { Lutino }\end{array}$ & 49 \\
\hline 5 & $\begin{array}{l}\text { L1: [KC1.5], [KC2.5], [KC3.5], [KC4.3], [KC5.7], [KC6.5] ; L3: } \\
\text { [KC1.1], [KC2.3], [KC3.1], [KC4.1], [KC5.1], [KC6.5] }\end{array}$ & 0.789 & 0.790 & $\begin{array}{l}\text { Lovebird } \\
\text { Albino }\end{array}$ & 9 \\
\hline 6 & $\begin{array}{l}\text { L1: [KC1.1], [KC2.5], [KC3.5], [KC4.3], [KC5.1], [KC6.3] ; L4: } \\
\text { [KC1.3], [KC2.3], [KC3.3], [KC4.1], [KC5.5], [KC6.5] ; L5: [KC1.1], } \\
\text { [KC2.1], [KC3.1], [KC4.3], [KC5.3], [KC6.1] }\end{array}$ & 0.4316 & 0.432 & $\begin{array}{l}\text { Lovebird } \\
\text { Pied }\end{array}$ & 59 \\
\hline 7 & $\begin{array}{l}\text { L2: [KC1.5], [KC2.5], [KC3.3], [KC4.3], [KC5.7], [KC6.5] ; L4: } \\
{[\text { KC1.1], [KC2.1], [KC3.1], [KC4.1], [KC5.1], [KC.5] }}\end{array}$ & 0.799 & 0.799 & $\begin{array}{l}\text { Lovebird } \\
\text { Lutino }\end{array}$ & 4 \\
\hline 8 & $\begin{array}{l}\text { L2: [KC1.5], [KC2.1], [KC3.5], [KC4.3], [KC5.3], [KC6.3] ; L5: } \\
\text { [KC1.1], [KC2.3], [KC3.3], [KC4.5], [KC5.7], [KC6.1] ; L6: [KC1.3], } \\
\text { [KC2.3], [KC3.3], [KC4.1], [KC5.5], [KC6.1] }\end{array}$ & 0.4528 & 0.453 & $\begin{array}{l}\text { Lovebird } \\
\text { Lutino }\end{array}$ & 57 \\
\hline 9 & $\begin{array}{l}\text { L3: [KC1.5], [KC2.5], [KC3.5], [KC4.5], [KC5.7], [KC6.1] ; L4: } \\
\text { [KC1.3], [KC2.1], [KC3.1], [KC4.1], [KC5.3], [KC6.1] }\end{array}$ & 0.743 & 0.743 & $\begin{array}{l}\text { Lovebird } \\
\text { Golden } \\
\text { Cherry }\end{array}$ & 20 \\
\hline 10 & $\begin{array}{l}\text { L3: [KC1.3], [KC2.3], [KC3.3], [KC4.1], [KC5.5], [KC6.1] ; L5: } \\
\text { [KC1.5], [KC2.3], [KC3.3], [KC4.5], [KC5.5], K[C6.5] }\end{array}$ & 0.6176 & 0.618 & $\begin{array}{l}\text { Lovebird } \\
\text { Cinnamon }\end{array}$ & 46 \\
\hline 11 & $\begin{array}{l}\text { L4: [KC1.5], [KC2.5], [KC3.5], [KC4.5], [KC5.7], [KC6.5] ; L1: } \\
\text { [KC1.1], [KC2.1], [KC3.1], [KC4.1], [KC5.1], [KC6.1] }\end{array}$ & 0.837 & 0.837 & $\begin{array}{l}\text { Lovebird } \\
\text { Pied }\end{array}$ & 1 \\
\hline 12 & $\begin{array}{l}\text { L2: [KC1.1], [KC2.1], [KC3.5], [KC4.1], [KC5.1], [KC6.3] ; L4: } \\
{[\text { KC1.5], [KC2.5], [KC3.1], [KC4.5], [KC5.5], [KC6.5] }}\end{array}$ & 0.623 & 0.623 & $\begin{array}{l}\text { Lovebird } \\
\text { Lutino }\end{array}$ & 44 \\
\hline 13 & $\begin{array}{l}\text { L6: [KC1.5], [KC2.5], [KC3.5], [KC4.3], [KC5.7], [KC6.3] ; L1: } \\
\text { [KC1.1], [KC2.1], [KC3.1], [KC4.3], [KC5.1], [KC6.1] }\end{array}$ & 0.793 & 0.793 & $\begin{array}{l}\text { Lovebird } \\
\text { Albino }\end{array}$ & 6 \\
\hline 14 & $\begin{array}{l}\text { L5: [KC1.3], [KC2.5], [KC3.5], [KC4.3], [KC5.5], [KC6.5] ; L3: } \\
\text { [KC1.3], [KC2.1], [KC3.1], [KC4.1], [KC5.1], K[C6.3] }\end{array}$ & 0.701 & 0.702 & $\begin{array}{l}\text { Lovebird } \\
\text { Cinnamon }\end{array}$ & 29 \\
\hline 15 & $\begin{array}{l}\text { L5: [KC1.1], [KC2.3], [KC3.3], [KC4.3], [KC5.3], [KC6.1] ; L6: } \\
\text { [KC1.5], [KC2.1], [KC3.1], [KC4.3], [KC5.7], [KC6.5] }\end{array}$ & 0.610 & 0.600 & $\begin{array}{l}\text { Lovebird } \\
\text { Biru }\end{array}$ & 48 \\
\hline 16 & $\begin{array}{l}\text { L3: [KC1.5], [KC2.3], [KC3.5], [KC4.5], [KC5.7], [KC6.3] ; L2: } \\
\text { [KC1.1], [KC2.3], [KC3.3], [KC4.1], [KC5.1], [KC6.1] }\end{array}$ & 0.759 & 0.760 & $\begin{array}{l}\text { Lovebird } \\
\text { Golden } \\
\text { Cherry }\end{array}$ & 16 \\
\hline 17 & $\begin{array}{l}\text { L3: [KC1.1], [KC2.5], [KC3.3], [KC4.5], [KC5.5], [KC6.5] ; L4: } \\
\text { [KC1.3], [KC2.3], [KC3.1], [KC4.3], [KC5.7], [KC6.3] ; L5: [KC1.5], } \\
\text { [KC2.1], [KC3.5], [KC4.3], [KC5.7], [KC6.3] ; L6: [KC1.1], [KC2.5], } \\
\text { [KC3.3], [KC4.5], [KC5.7], [KC6.1] }\end{array}$ & 0.353 & 0.353 & $\begin{array}{l}\text { Lovebird } \\
\text { Golden } \\
\text { Cherry }\end{array}$ & 62 \\
\hline 18 & $\begin{array}{l}\text { L5: [KC1.5], [KC2.5], [KC3.5], [KC4.3], [KC5.5], [KC6.5] ; L6: } \\
\text { [KC1.3], [KC2.1], [KC3.1], [KC4.3], [KC5.1], [KC6.1] }\end{array}$ & 0.733 & 0.733 & $\begin{array}{l}\text { Lovebird } \\
\text { Cinnamon }\end{array}$ & 22 \\
\hline 19 & $\begin{array}{l}\text { L4: [KC1.3], [KC2.5], [KC3.3], [KC4.1], [KC5.3], [KC6.5] ; L2: } \\
\text { [KC1.3], [KC2.5], [KC3.3], [KC4.3], [KC5.5], [KC6.5] }\end{array}$ & 0.556 & 0.556 & $\begin{array}{l}\text { Lovebird } \\
\text { Lutino }\end{array}$ & 51 \\
\hline 20 & $\begin{array}{l}\text { L1: [KC1.5], [KC2.5], [KC3.5], [KC4.1], [KC5.7], [KC6.5] ; L3: } \\
\text { [KC1.5], [KC2.1], [KC3.1], [KC4.1], [KC5.1], [KC6.3] }\end{array}$ & 0.666 & 0.666 & $\begin{array}{l}\text { Lovebird } \\
\text { Albino }\end{array}$ & 36 \\
\hline 21 & $\begin{array}{l}\text { L3: [KC1.5], [KC2.5], [KC3.3], [KC4.3], [KC5.3], [KC6.5] ; L5: } \\
\text { [KC1.3], [KC2.3], [KC3.3], [KC4.1], [KC5.1], [KC6.1] }\end{array}$ & 0.660 & 0.660 & $\begin{array}{l}\text { Lovebird } \\
\text { Golden } \\
\text { Cherry }\end{array}$ & 37 \\
\hline 22 & $\begin{array}{l}\text { L2: [KC1.5], [KC2.5], [KC3.5], [KC4.5], [KC5.7], [KC6.5] ; L4: } \\
{[\text { KC1.1], [KC2.3], [KC3.1], [KC4.3], [KC5.1], [KC6.1] }}\end{array}$ & 0.771 & 0.771 & $\begin{array}{l}\text { Lovebird } \\
\text { Lutino }\end{array}$ & 14 \\
\hline
\end{tabular}




\begin{tabular}{|c|c|c|c|c|c|}
\hline No & Alternative Code \& Preference Value & $\begin{array}{l}\text { System } \\
\text { Values }\end{array}$ & $\begin{array}{l}\text { Manual } \\
\text { Value }\end{array}$ & $\begin{array}{l}\text { Highest } \\
\text { Rank }\end{array}$ & Desc \\
\hline 23 & $\begin{array}{l}\text { L2: [KC1.1], [KC2.3], [KC3.1], [KC4.3], [KC5.1], [KC6.1] ; L5: } \\
\text { [KC1.5], [KC2.5], [KC3.3], [KC4.5], [KC5.1], [KC6.5] }\end{array}$ & 0.757 & 0.757 & $\begin{array}{l}\text { Lovebird } \\
\text { Lutino }\end{array}$ & 17 \\
\hline 24 & $\begin{array}{l}\text { L3: [KC1.5], [KC2.5], [KC3.5], [KC4.5], [KC5.7], [KC6.5] ; L4: } \\
\text { [KC1.1], [KC2.3], [KC3.1], [KC4.3], [KC5.3], [KC6.1] }\end{array}$ & 0.791 & 0.792 & $\begin{array}{l}\text { Lovebird } \\
\text { Golden } \\
\text { Cherry }\end{array}$ & 7 \\
\hline 25 & $\begin{array}{l}\text { L3: [KC1.3], [KC2.5], [KC3.3], [KC4.1], [KC5.5], [KC6.1] ; L5: } \\
\text { [KC1.5], [KC2.3], [KC3.3], [KC4.5], [KC5.5], [KC6.5] }\end{array}$ & 0.624 & 0.624 & $\begin{array}{l}\text { Lovebird } \\
\text { Cinnamon }\end{array}$ & 43 \\
\hline 26 & $\begin{array}{l}\text { L4: [KC1.1], [KC2.1], [KC3.5], [KC4.1], [KC5.3], [KC6.1] ; L1: } \\
\text { [KC1.5], [KC2.5], [KC3.3], [KC4.5], [KC5.1], [KC6.3] }\end{array}$ & 0.721 & 0.721 & $\begin{array}{l}\text { Lovebird } \\
\text { Albino }\end{array}$ & 25 \\
\hline 27 & $\begin{array}{l}\text { L2: [KC1.5], [KC2.5], [KC3.3], [KC4.5], [KC5.7], [KC6.5] ; L4: } \\
\text { [KC1.5], [KC2.1], [KC3.1], [KC4.1], [KC5.5], [KC6.1] }\end{array}$ & 0.697 & 0.697 & $\begin{array}{l}\text { Lovebird } \\
\text { Lutino }\end{array}$ & 30 \\
\hline 28 & $\begin{array}{l}\text { L6: [KC1.5], [KC2.3], [KC3.5], [KC4.3], [KC5.7], [KC6.5] ; L5: } \\
\text { [KC1.3], [KC2.1], [KC3.5], [KC4.1], [KC5.1], [KC6.3] }\end{array}$ & 0.646 & 0.647 & $\begin{array}{l}\text { Lovebird } \\
\text { Pied }\end{array}$ & 40 \\
\hline 29 & $\begin{array}{l}\text { L3: [KC1.5], [KC2.3], [KC3.5], [KC4.7], [KC5.3], [KC6.5] ; L5: } \\
\text { [KC1.1], [KC2.3], [KC3.1], [KC4.1], [KC5.1], [KC6.3] }\end{array}$ & 0.794 & 0.794 & $\begin{array}{l}\text { Lovebird } \\
\text { Golden } \\
\text { Cherry }\end{array}$ & 5 \\
\hline 30 & $\begin{array}{l}\text { L5: [KC1.1], [KC2.1], [KC3.5], [KC4.3], [KC5.7], [KC6.5] ; L6: } \\
\text { [KC1.5], [KC2.1], [KC3.1], [KC4.3], [KC5.7], [KC6.3] }\end{array}$ & 0.543 & 0.543 & $\begin{array}{l}\text { Lovebird } \\
\text { Biru }\end{array}$ & 52 \\
\hline 31 & $\begin{array}{l}\text { L1: [KC1.5], [KC2.5], [KC3.5], [KC4.3], [KC5.7], [KC6.5] ; L2: } \\
\text { [KC1.1], [KC2.1], [KC3.1], [KC4.1], [KC5.1], [KC6.3] }\end{array}$ & 0.800 & 0.800 & $\begin{array}{l}\text { Lovebird } \\
\text { Albino }\end{array}$ & 3 \\
\hline 32 & $\begin{array}{l}\text { L1: [KC1.3], [KC2.3], [KC3.1], [KC4.1], [KC5.7], [KC6.3]; L3: } \\
\text { [KC1.1], [KC2.5], [KC3.1], [KC4.1], [KC5.1], [KC6.3]; L4: [KC1.1], } \\
\text { [KC2.3], [KC3.5], [KC4.1], [KC5.1], [KC6.5] }\end{array}$ & 0.394 & 0.394 & $\begin{array}{l}\text { Lovebird } \\
\text { Albino }\end{array}$ & 61 \\
\hline 33 & $\begin{array}{l}\text { L4: [KC1.5], [KC2.5], [KC3.3], [KC4.5], [KC5.5], [KC6.3] ; L5: } \\
{[\text { KC1.3], [KC2.1], [KC3.1], [KC4.1], [KC5.1], [KC6.3] }}\end{array}$ & 0.724 & 0.725 & $\begin{array}{l}\text { Lovebird } \\
\text { Pied }\end{array}$ & 24 \\
\hline 34 & $\begin{array}{l}\text { L4: [KC1.3], [KC2.5], [KC3.1], K[C4.1], [KC5.5], [KC6.5] ; L2: } \\
\text { [KC1.3], [KC2.5], [KC3.3], [KC4.3], [KC5.5], [KC6.3] }\end{array}$ & 0.622 & 0.622 & $\begin{array}{l}\text { Lovebird } \\
\text { Lutino }\end{array}$ & 45 \\
\hline 35 & $\begin{array}{l}\text { L1: [KC1.1], [KC2.5], [KC3.3], [KC4.1], [KC5.3], [KC6.5] ; L3: } \\
\text { [KC1.5], [KC2.1], [KC3.5], [KC4.3], [KC5.7], [KC6.5] }\end{array}$ & 0.6839 & 0.684 & $\begin{array}{l}\text { Lovebird } \\
\text { Golden } \\
\text { Cherry }\end{array}$ & 33 \\
\hline 36 & $\begin{array}{l}\text { L1: [KC1.5], [KC2.5], [KC3.5], [KC4.5], [KC5.7], [KC6.5]; L4: } \\
\text { [KC1.3], [KC2.3], [KC3.3], [KC4.1], [KC5.5], [KC6.5] }\end{array}$ & 0.802 & 0.802 & $\begin{array}{l}\text { Lovebird } \\
\text { Albino }\end{array}$ & 2 \\
\hline 37 & $\begin{array}{l}\text { L2: [KC1.5], [KC2.5], [KC3.5], [KC4.5], [KC5.7], [KC6.1] ; L4: } \\
\text { [KC1.3], [KC2.1], [KC3.1], [KC4.1], [KC5.1], [KC6.5] }\end{array}$ & 0.730 & 0.730 & $\begin{array}{l}\text { Lovebird } \\
\text { Lutino }\end{array}$ & 23 \\
\hline 38 & $\begin{array}{l}\text { L2: [KC1.5], [KC2.5], [KC3.5], [KC4.3], [KC5.3], [KC6.3] ; L5: } \\
\text { [KC1.1], [KC2.3], [KC3.3], [KC4.3], [KC5.7], [KC6.1]; L6: [KC1.3], } \\
\text { [KC2.3], [KC3.3], [KC4.1], [KC5.5], [KC6.1] }\end{array}$ & 0.484 & 0.484 & $\begin{array}{l}\text { Lovebird } \\
\text { Lutino }\end{array}$ & 56 \\
\hline 39 & $\begin{array}{l}\text { L3: [KC1.5], [KC2.5], [KC3.3], [KC4.5], [KC5.5], [KC6.5] ; L4: } \\
\text { [KC1.3], [KC2.3], [KC3.1], [KC4.1], [KC5.1], [KC6.3] }\end{array}$ & 0.707 & 0.707 & $\begin{array}{l}\text { Lovebird } \\
\text { Golden } \\
\text { Cherry }\end{array}$ & 27 \\
\hline 40 & $\begin{array}{l}\text { L3: [KC1.3], [KC2.3], [KC3.3], [KC4.1], [KC5.5], [KC6.1] ; L5: } \\
\text { [KC1.5], [KC2.5], [KC3.3], [KC4.5], [KC5.5], [KC6.5] }\end{array}$ & 0.650 & 0.650 & $\begin{array}{l}\text { Lovebird } \\
\text { Cinnamon }\end{array}$ & 39 \\
\hline 41 & $\begin{array}{l}\text { L4: [KC1.5], [KC2.5], [KC3.3], [KC4.5], [KC5.5], [KC6.1] ; L1: } \\
{[\text { KC1.3], [KC2.3], [KC3.3], [KC4.1], [KC5.1], [KC6.1] }}\end{array}$ & 0.639 & 0.639 & $\begin{array}{l}\text { Lovebird } \\
\text { Pied }\end{array}$ & 42 \\
\hline 42 & $\begin{array}{l}\text { L2: [KC1.3], [KC2.1], [KC3.1], [KC4.1], [KC5.1], [KC6.3] ; L4: } \\
\text { [KC1.5], [KC2.3], [KC3.5], [KC4.5], [KC5.7], [KC6.5] }\end{array}$ & 0.748 & 0.748 & $\begin{array}{l}\text { Lovebird } \\
\text { Pied }\end{array}$ & 18 \\
\hline 43 & $\begin{array}{l}\text { L6: [KC1.5], [KC2.5], [KC3.5], [KC4.5], [KC5.7], [KC6.1] ; L1: } \\
\text { [KC1.3], [KC2.3], [KC3.3], [KC4.1], [KC5.1], [KC6.1] }\end{array}$ & 0.671 & 0.671 & $\begin{array}{l}\text { Lovebird } \\
\text { Biru }\end{array}$ & 34 \\
\hline 44 & $\begin{array}{l}\text { L3: [KC1.5], [KC2.5], [KC3.3], [KC4.5], [KC5.7], [KC6.3] ; L5: } \\
{[\text { KC1.1], [KC2.1], [KC3.3], [KC4.1], [KC5.1], [KC6.1] }}\end{array}$ & 0.768 & 0.768 & $\begin{array}{l}\text { Lovebird } \\
\text { Golden } \\
\text { Cherry }\end{array}$ & 15 \\
\hline 45 & $\begin{array}{l}\text { L5: [KC1.1], [KC2.3], [KC3.3], [KC4.3], [KC5.3], [KC6.5] ; L6: } \\
\text { [KC1.5], [KC2.1], [KC3.5], [KC4.3], [KC5.7], [KC6.5] }\end{array}$ & 0.6575 & 0.657 & $\begin{array}{l}\text { Lovebird } \\
\text { Biru }\end{array}$ & 38 \\
\hline 46 & $\begin{array}{l}\text { L1: [KC1.3], [KC2.5], [KC3.1], [KC4.5], [KC5.3], [KC6.3] ; L2: } \\
\text { [KC1.1], [KC2.3], [KC3.3], [KC4.5], [KC5.7], [KC6.1] }\end{array}$ & 0.560 & 0.560 & $\begin{array}{l}\text { Lovebird } \\
\text { Albino }\end{array}$ & 50 \\
\hline 47 & $\begin{array}{l}\text { L1: [KC1.1], [KC2.5], [KC3.1], [KC4.5], [KC5.3], [KC6.3] ; L2: } \\
\text { [KC1.1], [KC2.3], [KC3.3], [KC4.5], [KC5.7], [KC6.1]; L3: [KC1.5], } \\
\text { [KC2.1], [KC3.5], [KC4.3], [KC5.1], [KC6.3]; ;4: [KC1.3], [KC2.5], } \\
\text { [KC3.5], [KC4.1], [KC5.5], [KC6.5]; L5: [KC1.3], [KC2.5], [KC3.1], } \\
\text { [KC4.3], [KC5.7], [KC6.1]; L6 : [KC1.1], [KC2.5], [KC3.3], [KC4.1], } \\
\text { [KC5.7], [KC6.5] }\end{array}$ & 0.239 & 0.239 & $\begin{array}{l}\text { Lovebird } \\
\text { Golden } \\
\text { Cherry }\end{array}$ & 64 \\
\hline
\end{tabular}




\begin{tabular}{|c|c|c|c|c|c|}
\hline No & Alternative Code \& Preference Value & $\begin{array}{l}\text { System } \\
\text { Values }\end{array}$ & $\begin{array}{l}\text { Manual } \\
\text { Value }\end{array}$ & $\begin{array}{l}\text { Highest } \\
\text { Rank }\end{array}$ & Desc \\
\hline 48 & $\begin{array}{l}\text { L4: [KC1.5], [KC2.5], [KC3.3], [KC4.5], [KC5.5], [KC6.5] ; L5: } \\
\text { [KC1.1], [KC2.5], [KC3.1], [KC4.1], [KC5.1], [KC6.1] ; }\end{array}$ & 0.789 & 0.789 & $\begin{array}{l}\text { Lovebird } \\
\text { Pied }\end{array}$ & 10 \\
\hline 49 & $\begin{array}{l}\text { L4: [KC1.3], [KC2.5], [KC3.1], [KC4.1], [KC5.5], [KC6.5] ; L2: } \\
\text { [KC1.3], [KC2.5], [KC3.3], [KC4.3], [KC5.5], [KC6.3] }\end{array}$ & 0.612 & 0.612 & $\begin{array}{l}\text { Lovebird } \\
\text { Lutino }\end{array}$ & 47 \\
\hline 50 & $\begin{array}{l}\text { L1: [KC1.5], [KC2.5], [KC3.3], [KC4.1], [KC5.5], [KC6.5] ; L3: } \\
{[\text { KC1.5], [KC2.1], [KC3.5], [KC4.3], [KC5.1], [KC6.5] }}\end{array}$ & 0.515 & 0.515 & $\begin{array}{l}\text { Lovebird } \\
\text { Golden } \\
\text { Cherry }\end{array}$ & 54 \\
\hline 51 & $\begin{array}{l}\text { L1: [KC1.1], [KC2.5], [KC3.5], [KC4.3], [KC5.1], [KC6.1] ; L4: } \\
\text { [KC1.3], [KC2.3], [KC3.3], [KC4.1], [KC5.5], [KC6.5] ; L5: [KC1.1], } \\
\text { [KC2.5], [KC3.1], [KC4.3], [KC5.3], [KC6.1] }\end{array}$ & 0.4267 & 0.427 & $\begin{array}{l}\text { Lovebird } \\
\text { Pied }\end{array}$ & 60 \\
\hline 52 & $\begin{array}{l}\text { L2: [KC1.1], [KC2.3], [KC3.1], [KC4.1], [KC5.5], [KC6.1] ; L4: } \\
\text { [KC1.5], [KC2.5], [KC3.5], [KC4.5], [KC5.7], [KC6.1] }\end{array}$ & 0.792 & 0.791 & $\begin{array}{l}\text { Lovebird } \\
\text { Pied }\end{array}$ & 8 \\
\hline 53 & $\begin{array}{l}\text { L2: [KC1.1], [KC2.3], [KC3.1], [KC4.1], [KC5.1], [KC6.1] ; L5: } \\
\text { [KC1.5], [KC2.5], [KC3.3], [KC4.5], [KC5.1], [KC6.5] }\end{array}$ & 0.787 & 0.787 & $\begin{array}{l}\text { Lovebird } \\
\text { Lutino }\end{array}$ & 11 \\
\hline 54 & $\begin{array}{l}\text { L3: [KC1.3], [KC2.1], [KC3.3], [KC4.1], [KC5.1], [KC6.1] ; L1: } \\
\text { [KC1.3], [KC2.5], [KC3.5], [KC4.5], [KC5.5], [KC6.3] }\end{array}$ & 0.668 & 0.668 & $\begin{array}{l}\text { Lovebird } \\
\text { Albino }\end{array}$ & 35 \\
\hline 55 & $\begin{array}{l}\text { L3: [KC1.3], [KC2.3], [KC3.3], [KC4.1], [KC5.5], [KC6.1] ; L5: } \\
\text { [KC1.5], [KC2.3], [KC3.3], [KC4.5], [KC5.7], [KC6.5] }\end{array}$ & 0.640 & 0.640 & $\begin{array}{l}\text { Lovebird } \\
\text { Cinnamon }\end{array}$ & 41 \\
\hline 56 & $\begin{array}{l}\text { L4: [KC1.5], [KC2.5], [KC3.5], [KC4.5], [KC5.3], [KC6.1] ; L1: } \\
{[\text { KC1.3], [KC2.1], [KC3.3], [KC4.1], [KC5.1], [KC6.1] }}\end{array}$ & 0.690 & 0.690 & $\begin{array}{l}\text { Lovebird } \\
\text { Pied }\end{array}$ & 31 \\
\hline 57 & $\begin{array}{l}\text { L2: [KC1.3], [KC2.1], [KC3.1], [KC4.1], [KC5.5], [KC6.1] ; L4: } \\
\text { [KC1.5], [KC2.5], [KC3.5], [KC4.5], [KC5.1], [KC6.5] }\end{array}$ & 0.746 & 0.746 & $\begin{array}{l}\text { Lovebird } \\
\text { Pied }\end{array}$ & 19 \\
\hline 58 & $\begin{array}{l}\text { L6: [KC1.5], [KC2.5], [KC3.3], [KC4.5], [KC5.5], [KC6.3] ; L1: } \\
\text { [KC1.1], [KC2.3], [KC3.1], [KC4.3], [KC5.1], [KC6.5] }\end{array}$ & 0.741 & 0.741 & $\begin{array}{l}\text { Lovebird } \\
\text { Biru }\end{array}$ & 21 \\
\hline 59 & $\begin{array}{l}\text { L3: [KC1.1], [KC2.5], [KC3.1], [KC4.3], [KC5.3], [KC6.5] ; L5: } \\
\text { [KC1.1], [KC2.3], [KC3.3], [KC4.5], [KC5.7], [KC6.1] ; L6: [KC1.3], } \\
\text { [KC2.3], [KC3.5], [KC4.1], [KC5.1], [KC6.5] }\end{array}$ & 0.4338 & 0.434 & $\begin{array}{l}\text { Lovebird } \\
\text { Biru }\end{array}$ & 58 \\
\hline 60 & $\begin{array}{l}\text { L5: [KC1.5], [KC2.3], [KC3.3], [KC4.3], [KC5.3], [KC6.1] ; L6: } \\
\text { [KC1.5], [KC2.5], [KC3.1], [KC4.3], [KC5.7], [KC6.5] }\end{array}$ & 0.5179 & 0.518 & $\begin{array}{l}\text { Lovebird } \\
\text { Cinnamon }\end{array}$ & 53 \\
\hline 61 & $\begin{array}{l}\text { L4: [KC1.3], [KC2.5], [KC3.5], [KC4.1], [KC5.5], [KC6.5] ; L2: } \\
\text { [KC1.3], [KC2.5], [KC3.3], [KC4.3], [KC5.7], [KC6.3] }\end{array}$ & 0.506 & 0.506 & $\begin{array}{l}\text { Lovebird } \\
\text { Lutino }\end{array}$ & 55 \\
\hline 62 & $\begin{array}{l}\text { L1: [KC1.1], [KC2.5], [KC3.3], [KC4.1], [KC5.5], [KC6.3] ; L3: } \\
\text { [KC1.5], [KC2.1], [KC3.5], [KC4.3], [KC5.7], [KC6.5] }\end{array}$ & 0.687 & 0.687 & $\begin{array}{l}\text { Lovebird } \\
\text { Golden } \\
\text { Cherry }\end{array}$ & 32 \\
\hline 63 & $\begin{array}{l}\text { L1: [KC1.1], [KC2.5], [KC3.1], [KC4.1], [KC5.3], [KC6.1] ; L4: } \\
\text { [KC1.5], [KC2.5], [KC3.3], [KC4.5], [KC5.7], [KC6.5] }\end{array}$ & 0.784 & 0.784 & $\begin{array}{l}\text { Lovebird } \\
\text { Albino }\end{array}$ & 13 \\
\hline 64 & $\begin{array}{l}\text { L2: [KC1.5], [KC2.1], [KC3.5], [KC4.5], [KC5.1], [KC6.5] ; L4: } \\
\text { [KC1.3], [KC2.1], [KC3.1], [KC4.1], [KC5.1], [KC6.3] }\end{array}$ & 0.708 & 0.708 & $\begin{array}{l}\text { Lovebird } \\
\text { Lutino }\end{array}$ & 26 \\
\hline
\end{tabular}

Referring to Table 14 contains the results of 64 data testing scenarios input alternative sample data based on lovebird type and sub-criteria obtained an accuracy rate of $100 \%$ with true test data as much as 64 out of 64 total tests by manual calculation and system calculation. Good quality lovebird determination tests were conducted as many as 64 tests of evidence of different input samples. Of the 64 best rankings, the first rank lovebird is Lovebird Pied with a value 0.837 . From the experiment, the table was created containing alternative codes for the bird's name and weight preference criteria, the results of manual calculation values, the results of system calculation values, the highest ranking of the bird's name, and description of the rating of each lovebird.
Table 15. Basic Accuracy Percentage Assessment

\begin{tabular}{cc}
\hline Category Level & Percentage Value \\
\hline Very Low & $0 \%-20 \%$ \\
Low & $21 \%-40 \%$ \\
Moderate & $41 \%-60 \%$ \\
High & $61 \%-80 \%$ \\
Very High & $81 \%-100 \%$ \\
\hline
\end{tabular}

In Table 15(Kurniawan, 2017) shows the accuracy of the system accuracy which refers to the test results from table 14 it can be concluded that there are 3 levels of categories where as many as 4 users or about $6 \%$ of 64 tests with Low accuracy category levels in the results of lovebird immersion best with a percentage value of $21 \%-40 \%$. Furthermore, as many as 12 users or about $19 \%$ of 64 tests with a Moderate accuracy category level in the best lovebird communication results with a percentage value of $41 \%-60 \%$ Then as many as 48 users or 
JURNAL RISET INFORMATIKA

Vol. 4, No. 1 December 2021
P-ISSN: 2656-1743 |E-ISSN: 2656-1735

DOI: https://doi.org/10.34288/jri.v4i1.305 about $75 \%$ of 64 tests with a High accuracy category level in the results of lovebird communication best with a percentage value of $61 \%-80 \%$. And there are no users whose percentage value is below $20 \%$ or very low and above $81 \%$ or very high that has been recommended by the system or manually.

\section{CONCLUSION}

Based on the results of research and design obtained a website-based application system on identifying the selection of quality lovebirds designed with Native PHP programming and MySQL as databases. This application contains 6 criteria data consisting of each of 3 physical subcriteria of lovebird and 6 alternative data of selected lovebird names in the same species. In addition, this application also combines 2 methods namely analytical hierarchy process and weighted product with test conclusions on 64 alternative sample evidence based on lovebird type and sub-criteria both in system calculations and manual calculations that result in low accuracy category levels. with a percentage value of 21\%-40\%. Furthermore, as many as 12 users or about $19 \%$ of 64 tests with a moderate accuracy category level with a percentage value of $41 \%-60 \%$ Then as many as 48 users or about $75 \%$ of 64 tests with a high accuracy category level in the best lovebird communication results with a percentage value of $61 \%-80 \%$. This decision support system as an application that produces the highest ranking in helping recommend the decision of determining the best quality lovebird. This designed application can still be developed even better and is recommended for its development to be used with other methods and implementations

\section{REFERENCE}

Amalia, E. L., RDA, R. A., \& Pratama, A. N. (2019). Sistem Pendukung Keputusan Menentukan Lovebird Unggul dalam Perlombaan Menggunakan Metode AHP-Topsis. Matics, 11(1), https://doi.org/10.18860/mat.v11i1.7690

Andriyani, S., \& Yuma, F. M. (2020). Kombinasi Metode Analitical Hierarchy Process Dan Weighted Product Dalam Penentuan Benih Cabai Unggul. 6(2), 117-124.

Bahtiar, S., Gunawan, I., Safii, M., \& Parlina, I. (2019). Implementasi Dengan Metode Promethee Dalam Merekomendasikan Keputusan Juri Pada Kompetisi Burung Lovebird. 1, 658-663.

Charli, F., Syaputra, H., Akbar, M., Sauda, S., \& Panjaitan, F. (2020). Implementasi Metode Faster Region Convolutional Neural Network (Faster R-CNN) Untuk Pengenalan Jenis
Burung Lovebird. Journal of Information Technology Ampera, 1(3), 185-197. https://doi.org/10.51519/journalita.volume 1.isssue3.year2020.page185-197

Defit, S., Nurcahyo, G. W., Studi, P., \& Ilmu, M. (2021). Decision Support System in Identification of Swallow's Nest Quality with Weighted Product Method.3(1), 181-192.

DLHK Provinsi Banten. (2019). Mengenal Satwa Tidak Dilindungi (Simungil Burung Cinta/ Lovebird). Retrieved from DLHK Provinsi Banten website: https://www.dlhk.bantenprov.go.id/read/ar ticle/838/Mengenal-Satwa-Tidak-

Dilindungi-Simungil-Burung-Cinta-

Lovebird.html

Imam, S. (2020). Pengaruh Harga, Kualitas Produk Dan Gaya Hidup Terhadap Pengambilan Keputusan Pembelian Burung Lovebird (Studi Kasus Pasar Unggas Kedungwuni Kabupaten Pekalongan). Jurnal Ekonomi Islam, (Marketing Mix), 43.

Krismadewi, P. (2021). Pemilihan supplier ayam broiler PT. Sentral Unggas Perkasa (SUP) menggunakan metode Analytical Hierarchy Process (AHP) dan Weighted Product (WP). Universitas Islam Negeri Sunan Ampel Surabaya.

Kurniawan, Y. I. (2017). Sistem Pendukung Keputusan Penentuan Kelolosan Beasiswa Sekolah Menengah Kejuruan (SMK) menggunakan Metode Fuzzy. Jurnal Teknik Elektro, 9(1), 13-17. https://doi.org/10.15294/jte.v9i1.9322

Novira, S. T., Mubarok, H., \& Shofa, R. N. (2020). Sistem Pendukung Keputusan Pemilihan Jurusan dengan menggunakan Metode Analytical Hierarchy Process dan Weighted Product (Studi Kasus: SMK Al-Khoeriyah Kota Tasikmalaya). SAIS/ Scientific Articles of Informatics Students, 3(2), 111-122.

Nurajizah, S., Ambarwati, N. A., \& Muryani, S. (2020). Sistem Pendukung Keputusan Pemilihan Internet Service Provider Terbaik Dengan Metode Analytical Hierarchy Process. JURTEKSI Uurnal Teknologi Dan Sistem Informasi), 6(3), 231-238. https://doi.org/10.33330/jurteksi.v6i3.632

Perdana, D. S., Defit, S., \& Sumijan, S. (2020). Sistem Pendukung Keputusan Menggunakan Metode Analytical Hierarchy Process (AHP) dalam Penentuan Kualitas Kulit Sapi dalam Produksi Kebutuhan Rumah Tangga. Jurnal Informasi Dan Teknologi, 3, 84-89. https://doi.org/10.37034/jidt.v3i2.100

Ramadhan, A. A., Suprianto, Surmarno, \& Dijaya, R. (2021). Decision Support System for Selection of Quality Doves with Web-Based Analytical 
Hierarchy Process (AHP) Methods. Procedia of Engineering and Life Science, 1(2). https://doi.org/10.21070/pels.v1i2.929

Rudiantoro, R., Cholissodin, I., \& Dewi, R. K. (2019). Rekomendasi Pemilihan Burung Menggunakan Metode Simple Additive Weighting (SAW) dan Technique Order Preference by Similarity To Ideal Solution (TOPSIS). Jurnal Pengembangan Teknologi
Informasi Dan Ilmu Komputer (J-PTIIK) Universitas Brawijaya, 3(2), 8905-8911.

Sugianto, R. A., Roslina, R., \& Situmorang, Z. (2021). Kombinasi Metode Simple Additive Weigthing dan Weigthed Product Untuk Seleksi Proposal Program Kreatifitas Mahasiswa. Jurnal Media Informatika Budidarma, 5(2), 564. https://doi.org/10.30865/mib.v5i2.2929 